Gut, 1971, 12, 713-716

\title{
Influence of diet on flatus volume in human subjects
}

\author{
P. J. DAVIES
}

From the Department of Gastroenterology, Central Middlesex Hospital, London

SUMMARY Ten flatulent but otherwise healthy subjects were studied while consuming two or three different diets. Flatus collections showed that a bean-containing, high crude-fibre diet produced more flatus (mean $49.4 \mathrm{ml} / \mathrm{hr}$ ) than either a diet with a restricted crude-fibre content (mean $26.7 \mathrm{ml} /$ $\mathrm{hr}$ ) or a liquid chemically defined diet (mean $10.9 \mathrm{ml} / \mathrm{hr}$ ). There was a close correlation between the crude-fibre content of the diet and the production of flatus. The results are consistent with the conclusion that flatus is not the result of swallowing air, but arises mainly from bacterial fermentation of indigestible carbohydrate, eg, cellulose, passing into the colon.

Since the time of Hippocrates, clinicians have been interested in the effect of diet on flatulence. Fries (1906) was the first to measure flatus volume in man, when, in a single experiment, he noted the production of about 1 litre of flatus daily. Previous investigations into the effect of diet on the volume of flatus have shown highly divergent results.

Askevold (1956), using a rectal catheter, performed 286 flatus collections on three schizophrenic women while they were taking several diets with varying amounts of fibre, fat, carbohydrate, and protein. He was unable to demonstrate any significant effect of diet on flatus volume in these subjects.

On the other hand, Steggerda and Dimmick (1966) investigated the effect of beans on production of flatus by maintaining five healthy male subjects for seven days on five different diets containing increasing quantities of beans. Using only a twohour postprandial collection period on the fourth and seventh day of each dietary period, they showed a marked increase in flatus which was proportional to the amount of beans in the diet.

Blair, Dern, and Bates (1947) showed a $50 \%$ increase in flatus when their subjects consumed either a high carbohydrate diet or one containing $4 \%$ soy protein. Kirk (1949) was more interested in the fibre content of the diet. He investigated 12 normal subjects who consumed either a cabbage-free diet or one containing $600 \mathrm{~g}$ of brussel sprouts. The inclusion of the brussel sprouts increased flatus volume by $44 \%$.

It is the purpose of this communication to report

Received for publication 8 July 1971.

Present address for correspondence and reprints: Dr Peter J. Davies, St Vincent's Hospital, Melbourne, Victoria 3065, Australia. the effect of three carefully chosen diets on volumes of flatus of flatulent subjects using prolonged and repeated collections, and briefly to consider the mechanisms involved in producing flatus in these subjects.

\section{Materials and Methods}

Ten subjects were studied, six women and four men. Ages ranged from 25 to 65 years. All subjects were troubled by excessive flatus, and all had been thoroughly investigated at the gastroenterological outpatients' clinic; no evidence had been found of organic disease. The nature of the study was explained to the patients who all willingly consented to these investigations.

The composition of the three diets is given in Table I. Each diet contained approximately 1,800

\begin{tabular}{llclll}
\hline Diet & $\begin{array}{l}\text { Carbohydrate } \\
(g)\end{array}$ & Fat $(g)$ & $\begin{array}{l}\text { Protein } \\
(g)\end{array}$ & $\begin{array}{l}\text { Crude Fibre } \\
(g)\end{array}$ & Calories \\
\hline A & $406 \cdot 8$ & $1 \cdot 33$ & 38 & 0 & 1,800 \\
B & 100 & 108 & 87 & $2 \cdot 4$ & 1,751 \\
C & 148 & 108 & 64 & $9 \cdot 4$ & 1,810 \\
\hline
\end{tabular}

Table I Composition (per day) of the diets

calories. Diet A was a high carbohydrate, liquid chemically defined diet (Vivasorb). Diet B had a restricted quantity of carbohydrate and a low crude fibre content. Diet $\mathrm{C}$ had a high crude fibre content and contained $20 \%$ by weight of a proprietary brand of baked beans. The beans accounted for $35 \%$ of the carbohydrate and $57 \%$ of the crude fibre content of this diet. Each diet was weighed and issued by a dietician, and the allocation order of the diets was 
varied. Three meals daily were served at $900 \mathrm{am}$, $1230 \mathrm{pm}$, and $500 \mathrm{pm}$.

Immediately after breakfast each subject was requested to defaecate. Laxatives, purgatives, or enemas were not used because of their effects on colonic motility. After defaecation a rectal catheter was inserted $9 \mathrm{~cm}$ beyond the anus for flatus collection. Before the present study a pilot trial was conducted to test techniques for collecting flatus. The most suitable rectal catheter was the St. Bartholomew's barium enema catheter which has an inflatable balloon and three large perforations near its tip. Flatus was collected by the displacement of water in an inverted gas jar according to the method of Alstead and Patterson (1948). The collection period was six hours. In view of the known effects of somatic activity on propulsion (mass movements) in the human colon (Holdstock, Misiewicz, Smith, and Rowlands, 1970) the amount of physical activity during the collection period was standardized by the performance of a set of exercises at hourly intervals.

There were 13 satisfactory collections from the first five subjects while taking diets B and C. Subjects 6-10 were studied over a three-week period while being maintained on each of the three diets for seven consecutive days. There were 43 satisfactory collections over this period. Out of a total of 68 collections, 12 were unsatisfactory because of faeces blocking the catheter, but blockage was usually not a problem provided that the rectum was completely evacuated at the time of defaecation.

\section{Results}

The results are summarized in Table II. The average flatus volumes on the three diets were: $10.9 \mathrm{ml} / \mathrm{hr}$ on diet A (Vivasorb); $26.7 \mathrm{ml} / \mathrm{hr}$ on diet B (restricted carbohydrate and crude fibre); $49.4 \mathrm{ml} / \mathrm{hr}$ on diet C (bean-containing, high crude fibre diet). Standard deviations were not recorded because the results

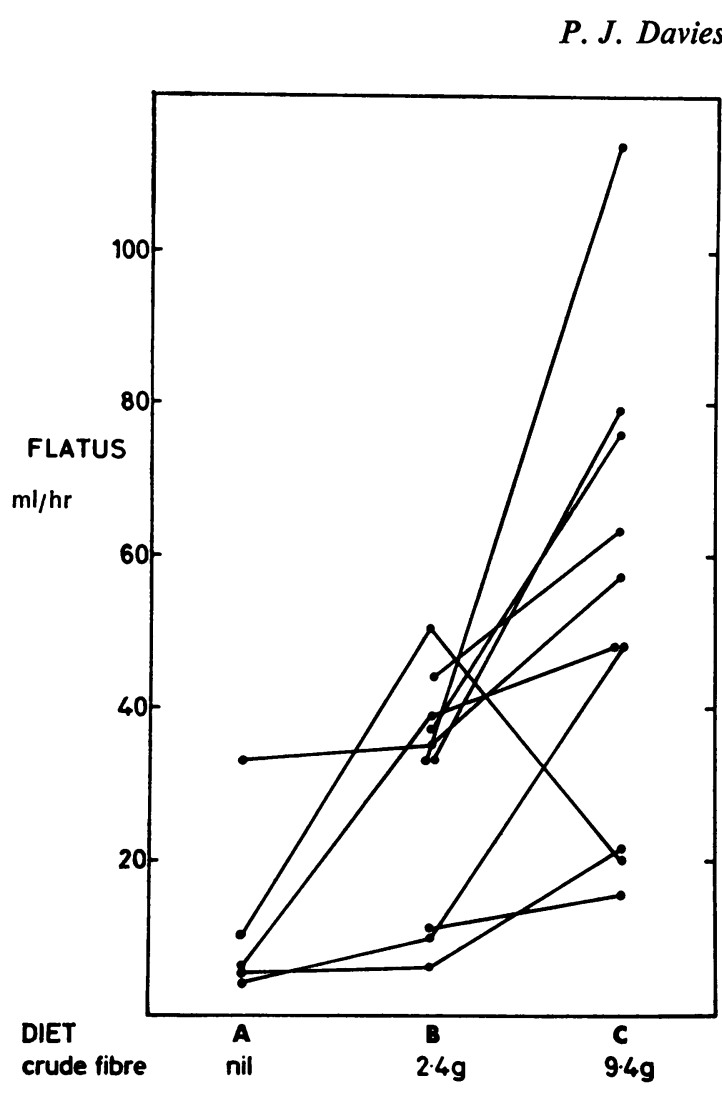

Fig. 1 Changes in mean flatus volumes for each subject

from diet A took the form of a log normal distribution. When the means for each subject were compared according to the $t$ test, there was a highly significant increase in the volume of flatus for subjects taking diet $C$ compared with the same subjects taking diet $\mathrm{A}(\mathrm{P}<0.01)$ or diet $\mathrm{B}(\mathrm{P}<$ $0.05)$. In the more prolonged studies with subjects 6-10 there was on average a $221 \%$ increase in flatus

\begin{tabular}{|c|c|c|c|c|c|c|c|c|c|c|c|}
\hline \multirow[t]{2}{*}{ Subject } & \multirow[t]{2}{*}{ Sex } & \multirow[t]{2}{*}{ Age } & \multicolumn{3}{|l|}{ Diet $A$} & \multicolumn{3}{|l|}{ Diet $B$} & \multicolumn{3}{|c|}{ Diet $C$} \\
\hline & & & Mean & $n$ & Range & Mcan & $n$ & Range & Mean & $n$ & Range \\
\hline 1 & $\mathbf{M}$ & 25 & & & & 33 & 1 & & 79 & 1 & \\
\hline 2 & $\mathbf{F}$ & 39 & & & & 33 & $\overrightarrow{1}$ & & 114 & 1 & \\
\hline 3 & $\mathbf{F}$ & 53 & & & & 44 & 2 & $29-58$ & 63 & 2 & $52-73$ \\
\hline 4 & $\mathbf{M}$ & 30 & & & & 11 & 2 & $1-21$ & 15 & 1 & \\
\hline 5 & $\mathbf{F}$ & 45 & & & & 38 & 1 & & 77 & 1 & \\
\hline 7 & $\mathbf{M}$ & 65 & 10 & 2 & 2-17 & 48 & 2 & $38-57$ & 20 & 1 & \\
\hline 8 & $\mathbf{F}$ & 34 & 5 & 3 & 2- 9 & 6 & $\overline{5}$ & $3-12$ & 21 & 4 & $7-30$ \\
\hline 9 & $\mathbf{M}$ & 57 & 6 & 5 & $2-13$ & 39 & 3 & $28-49$ & 48 & 3 & $22-69$ \\
\hline 10 & $\mathbf{F}$ & 29 & 4 & 3 & $2-6$ & 10 & 1 & & 48 & 1 & \\
\hline
\end{tabular}

Table II Results of flatus collections in 10 subjects ${ }^{1}$

${ }^{1}$ Flatus volumes in $\mathrm{ml} / \mathrm{hr}$.

$\mathrm{n}=$ number of satisfactory collections. 
production on changing from $\operatorname{diet} \mathbf{A}$ to $\operatorname{diet} \mathbf{B}$. This with a paired $t$ test just failed to reach significance $(P<0.01)$. Only subject no. 7 had a decrease in flatus while taking diet $\mathrm{C}$ : for technical reasons only one satisfactory collection was obtained from this subject while taking the bean diet.

The changes in the mean flatus volumes for each subject are plotted graphically in Figure 1. It is apparent that there is a close correlation between increasing the crude fibre content of the diet and enhanced production of flatus.

\section{Discussion}

VARIABILITY OF FLATUS VOLUME

There are two important factors which help to explain much of the controversy in the earlier literature. As can be seen from Table II, there is a considerable day-to-day variation in flatus production in subjects taking the same diet. Repeated collections are therefore necessary. The second problem lies in the technique of collecting flatus. Blockage of the catheter is likely if faeces are retained in the rectum after defaecation. Likewise, subjects with diarrhoea cannot be studied. Many of the earlier reports clearly failed to consider these problems sufficiently.

CARBOHYDRATE DIGESTIBILITY AND FLATUS The results reported here suggest that the type of carbohydrate in the diet is an important factor in flatus production. Murphy (1964) also found low flatus volumes in subjects fed a chemically defined (astronaut's) diet. If gas production was largely the result of fermentation of undigested carbohydrate, it would be anticipated that subjects fed Vivasorb would have low flatus volumes, since this diet is well absorbed in the proximal small intestine where Drasar, Shiner, and McLeod (1969) have shown only small numbers of bacteria to be present normally. Furthermore, Winitz, Adams, Seedman, Davis, Jayko, and Hamilton (1970) found that the provision of a glucose-based chemically defined diet as the sole means of nutritional support to four healthy subjects was accompanied by a marked reduction in faecal microflora.

Steggerda (1968) found that the gas-forming components of soy bean included the indigestible oligosaccharides of the stachyose and raffinose type, and furthermore he showed that gas production by the anaerobic bacterial fermentation of soy bean homogenates could be markedly inhibited by antibiotics and bacteriostatic agents. It is of further interest that a trypsin inhibitor has been identified in soy bean (Finkenstadt and Laskowski, 1965).
SWALLOWED AIR AND FLATUS

It is currently believed that about $70 \%$ of alimentary gas is swallowed air (Alvarez, 1942; Andersen and Ringsted, 1943; Saltzman and Sieker, 1968). Wangensteen and Rea (1939) showed that swallowed air was the most important factor in producing abdominal distension in dogs with mechanical intestinal obstruction. Maddock, Bell, and Tremaine (1949) showed that when nervous subjects were subjected to unpleasant investigations such as pyelography, they could swallow large volumes of air which was sometimes passed as flatus within 30 minutes. However, it seems unlikely that the fourfold increase in flatus production in the present study can be explained solely on the basis of air swallowing, especially in view of Hood's finding that adults swallow more air with liquids than with solids (Hood, 1966). Furthermore, the composition of flatus collected after a bean meal argues against air swallowing as the causative factor. Steggerda and Dimmick (1966) found low concentrations of nitrogen $(19-37.7 \%)$ and high concentrations of gases produced by fermentation, such as carbon dioxide $(23 \cdot 1-51 \cdot 4 \%)$, methane $(13.9-22.4 \%)$, and hydrogen $(8-27 \%)$.

\section{PRODUCTION OF FLATUS IN THE COLON}

Levitt and Ingelfinger (1968) used a constant infusion technique to obtain quantitative data on hydrogen and methane production in healthy man. They found that hydrogen was produced in all subjects, was mainly confined to the large intestine, and was almost completely dependent upon ingested fermentable substances. Calloway (1966) showed that the peak breath hydrogen concentration occurred about five or six hours after a bean meal, ie, at a time when food residues reach the lower ileum and upper colon where bacteria are abundant.

FERMENTATION OF CRUDE FIBRE

Enteric microflora are capable of fermenting urea and most of the organic substances present in foods but not lignin (Calloway, Colasito, and Matthews, 1966). Earlier workers (Williams and Olmsted, 1936; Humel, Shepherd, and Macy, 1943) have shown the disappearance of cellulose during its passage through the gut of man. In a recent careful study over a nineday period on a single subject, only $42.5 \%$ of ingested cellulose was recovered in the faeces, using copper thiocyanate as a marker (Milton-Thompson, 1971). Although the enzyme cellulase has not been demonstrated in the gastrointestinal mucosa or pancreatic secretions of man, Mangold (1934) showed that the gases produced by faecal bacterial fermentation of cellulose in human subjects included carbon dioxide, methane, and hydrogen. More 
recently, Milton-Thompson (1971) has recovered ${ }^{14} \mathrm{CO}_{2}$ from the breath of several subjects fed ${ }^{14} \mathrm{C}$ labelled cellulose. Finally, Goldstein, Karacadag, Wirts, and Kowlessar (1970) have shown in men that coliform bacteria are able to utilize the hemicellulose, D-xylose, for their own metabolism.

It is concluded, therefore, that the most important factor in the production of flatus is the fermentation of undigested food residues by colonic microflora.

I thank Sir Francis Avery Jones and Dr T. D. Kellock for allowing me to study their patients, Dr E. N. Rowlands for providing technical help, and Mrs J. Mottram for preparing the diets. I am most grateful to the Central Middlesex Hospital Research Committee who provided a grant for the study, and the Vivonex Corporation who supplied the Vivasorb. I would also like to thank Dr Philip James and Dr Hugh McMichael for their help and advice in the preparation of this manuscript.

\section{References}

Alstead, S., and Patterson, J. F. (1948). Assessment of intestinal carminatives. Lancet, 1, 437-439.

Alvarez, W. C. (1942). What causes flatulence? J. Amer. med. Ass., $120,1,21-24$.

Andersen, K., and Ringsted, A. (1943). Clinical and experimental investigations on ileus with particular reference to the genesis of intestinal gas. Acta chir. scand., 88, 475-502.

Askevold, F. (1956). Investigations on the influence of diet on the quantity and composition of intestinal gas in humans. Scand. J. clin. Lab. Invest., 8, 87-94.

Blair, H. A., Dern, R. J., and Bates, P. L. (1947). The measurement of volume of gas in the digestive tract.Amer.J. Physiol.,149, 688707.

Calloway, D. H. (1966). Respiratory hydrogen and methane as affected by consumption of gas-forming foods. Gastroenterology, 51, 383-389.

Calloway, D. H., Colasito, D. J., and Matthews, R. D. (1966). Gases produced by human intestinal microflora. Nature (Lond.), 212, 1238-1239.
Drasar, B. S., Shiner, M., and McLeod, G. M. (1969). Studies on the intestinal flora, I. The bacterial flora of the gastrointestinal tract in healthy and achlorhydric persons. Gastroenterology, 56, 71-79.

Finkenstadt, W. R., and Laskowski, M. Jr. (1965). Peptide bond cleavage on trypsin-trypsin inhibitor complex formation. J. biol. Chem., 240, 2, 962-964.

Fries, J. A. (1906). Intestinal gases of man. Amer. J. Physiol., 16, 468-474.

Goldstein, F., Karacadag, S., Wirts, C. W., and Kowlessar, O. D. (1970). Intraluminal small-intestinal utilization of d-xylose by bacteria. Gastroenterology, 59, 380-386.

Holdstock, D. J., Misiewicz, J. J., Smith, T., and Rowlands, E. N. (1970). Propulsion (mass movements) in the human colon and its relationship to meals and somatic activity. Gut, 11, 91-99.

Hood, J. H. (1966). Clinical considerations of intestinal gas. Ann Surg., 163, 359-366.

Hummel, F. C., Shepherd, M. L., and Macy, I. G. (1943). Disappearance of cellulose and hemicellulose from the digestive tracts of children. J. Nutr., 25, 59-70.

Kirk, E. (1949). The quantity and composition of human colonic flatus. Gastroenterology, 12, 782-794.

Levit t, M. D., and Ingelfinger, F. J. (1968). Hydrogen and methane production in man. Ann. N.Y. Acad. Sci., 150, 75-81.

Maddock, W. G., Bell, J. L., and Tremaine, M. J.(1949). Gastro-intestinal gas: observations on belching during anesthesia, operations and pyelography; and rapid passage of gas. Ann. Surg., 130, 512-537.

Mangold, E. (1934). The digestion and utilization of crude fibre. Nutr. Abstr. Rev., 3, 647-656.

Milton-Thompson, G. J. (1971). Research Department, St. Mark's Hospital, London. Personal communication.

Murphy, E. L. (1964). Flatus. In Conference on Nutrition in Space and Relaled Waste Problems. Tampa, Florida. N.A.S.A. Document, SP-70, pp, 255-259. N.A.S.A., Washington, D.C.

Saltzman, H. A., and Sieker, H. O. (1968). Intestinal response to changing gaseous environments: normobaric and hyperbaric observations. Ann. N.Y. Acad. Sci., 150, 31-39.

Steggerda, F. R., and Dimmick, J. F. (1966). Effects of bean diets on concentration of carbon dioxide in flatus. Amer. J. clin. Nutr., 19, 120-124.

Steggerda, F. R. (1968). Gastrointestinal gas following food consumption. Ann. N.Y. Acad. Sci., 150, 57-66.

Wangensteen, O. H., and Rea, C. E. (1939). The distension factor in simple intestinal obstruction. Surgery, 5, 327-339.

Williams, R. D., and Olmsted, W. H. (1936). The manner in which food controls the bulk of the feces. Ann. intern. Med., 10, 717-727.

Winitz, M., Adams, R. F., Seedman, D. A., Davis, P. N. , Jayko, L. G., and Hamilton, J. A. (1970), Studies in metabolic nutrition employing chemically defined diets. II. Effects on gut microflora populations. Amer. J. clin. Nutr., 23, 546-559. 